\title{
Below- and aboveground abundance and distribution of fungal entomopathogens in experimental conventional and organic cropping systems
}

\author{
Nicolai V. Meyling ${ }^{\mathrm{a}, *}$, Kristian Thorup-Kristensen ${ }^{\mathrm{b}}$, Jørgen Eilenberg ${ }^{\mathrm{a}}$ \\ a Department of Agriculture and Ecology, Faculty of Life Sciences, University of Copenhagen, Thorvaldsensvej 40, DK-1871 Frederiksberg C, Denmark \\ b Department of Horticulture, Aarhus University, Kirstinebjergvej 10, DK-5792 Aarslev, Denmark
}

\section{H I G H L I G H T S}

Below- and aboveground communities of fungal entomopathogens were different.

- Metarhizium anisopliae was most common belowground, but absent aboveground.

- Beauveria bassiana was most commonly infecting arthropods aboveground.

- No differences were seen in belowground fungal communities between conventional and organic farming.

- More infected arthropod cadavers were recovered in conventional than in organic farming.

\section{A R T I C L E I N F O}

\section{Article history:}

Received 26 November 2010

Accepted 22 July 2011

Available online 31 July 2011

\section{Keywords:}

Fungal community ecology

Spatio-temporal dynamics

Entomopathogenic fung

Galleria bait method

Agricultural management
G R A P H I C A L A B S T R A C T

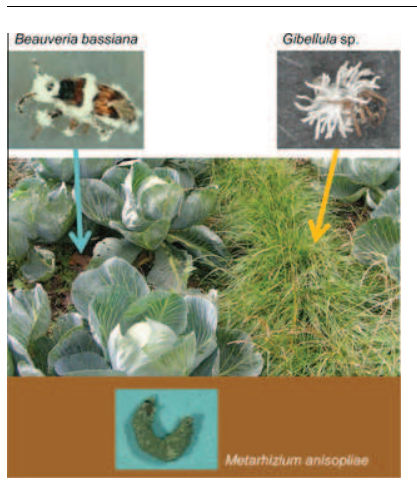

\begin{abstract}
A B S T R A C T
The below- and aboveground communities of fungal entomopathogens (Ascomycota: Hypocreales) were investigated in an experimental conventional and organic vegetable cropping system over two seasons in Denmark. The experimental design allowed for evaluating differences between farming practices in the occurrence of soil-borne fungal entomopathogens and as natural infections aboveground in arthropod hosts. Belowground, Metarhizium anisopliae dominated the agricultural field with Beauveria bassiana, Metarhizium flavoviride, and Isaria fumosorosea being present at lower frequencies. Abundances of M. anisopliae were not different between conventional and organic soils. Aboveground, B. bassiana was the most common fungal entomopathogen in arthropod host cadavers. Infections of M. flavoviride, Isaria farinosa, and Gibellula spp. were also recorded. Most mycosed cadavers were recovered in August and September from conventionally farmed plots. Cadaver sizes ranged from 1.9 to $23.6 \mathrm{~mm}$ with means of $3.7-4.1 \mathrm{~mm}$. Among host functional groups, predators dominated (47-63\%) over herbivores, parasitoids, and nectarfeeders. No occurrence of $M$. anisopliae was recorded among $>200$ mycosed cadavers aboveground. The results therefore suggest that $M$. anisopliae is not involved in direct below- and aboveground interactions in the investigated agroecosystem. Conservation biological control strategies targeting M. anisopliae should thus be solely for controlling soil-dwelling pests in temperate regions as this fungus is unlikely naturally to infect aboveground hosts in the agroecosytem.
\end{abstract}

(ㄷ) 2011 Elsevier Inc. All rights reserved.

\footnotetext{
* Corresponding author. Fax: +45 35332670 .

E-mail address: nvm@life.ku.dk (N.V. Meyling).
} 


\section{Introduction}

It is increasingly realized that below- and aboveground interactions are important for community structure and functioning of terrestrial ecosystems (van der Putten et al., 2001, 2009). Understanding these interactions in agricultural systems may improve crop protection but very few studies have integrated such approaches (van der Putten et al., 2009). Microbial communities decomposing organic matter in soil alter available nutrients for plants thereby affecting herbivore populations aboveground (van der Putten et al., 2009), and belowground decomposing communities can also negatively affect aboveground pest populations by enhancing natural enemy abundance (Birkhofer et al., 2008). Among natural enemies of pests, soil-borne fungal entomopathogens are widespread in temperate agroecosystems and semi-natural habitats (Hesketh et al., 2010; Vega et al., 2009; Meyling and Eilenberg, 2006, 2007). Additionally, many of the same fungal taxa are recovered aboveground in terrestrial ecosystems (Hesketh et al., 2010) indicating that below- and aboveground interactions may also include fungal entomopathogens. This knowledge is important for understanding the impact of the fungi in regulating host populations and for epizootic development (Hesketh et al., 2010; Vega et al., 2009), but it is necessary to study local spatiotemporal abundance and distribution of fungal entomopathogens to evaluate below- and aboveground interactions of these microorganisms.

Surveys of soil-borne fungal entomopathogens (Ascomycota: Hypocreales) have shown that some fungal taxa, particularly Metarhizium anisopliae (Metschnikoff) Sorokin, are abundant in agricultural field soils, but infrequent in soils of more natural habitats (Bidochka et al., 1998; Chandler et al., 1997; Meyling and Eilenberg, 2007; Vega et al., 2009). Whether the taxa locally abundant belowground reflect the range of fungal entomopathogens infecting aboveground hosts in the same ecosystem remains unclear since studies investigating fungal communities simultaneously below- and aboveground in individual ecosystems are limited. Beauveria bassiana (Balsamo) Vuillemin was shown to be soil-borne and to occur on plant surfaces and as latent infections in insect hosts aboveground within a hedgerow habitat (Meyling et al., 2009) indicating below- and aboveground interactions. Similarly, Ormond et al. (2010) reported B. bassiana to be present in soil and on foliage in the same forest ecosystem. In agricultural fields, spatio-temporal occurrence of below- and aboveground fungal entomopathogens has not been studied. Such knowledge is important for identifying the ecological niches occupied by the fungi within the agroecosystem and for evaluating the potential of particular fungal taxa in regulating arthropod pests.

Management practices enhancing the effect of indigenous natural enemies for pest control are particularly important in organic farming (Lammerts van Bueren et al., 2002; Birkhofer et al., 2008). Conversion from conventional to organic farming generally increases the diversity and activity of soil microorganisms over time (Mäder et al., 2002; Birkhofer et al., 2008), but the effects of organic farming on fungal entomopathogens in the soil are not clear. Communities of soil-borne fungal entomopathogens may be unaltered during transition to organic farming (Jabbour and Barbercheck, 2009), but some fungal taxa were shown to occur more frequently in organically farmed fields than in conventional fields (Klingen et al., 2002). Organic farming includes amendments of organic fertilizers and often the use of legumes as green manures (Axelsen and Kristensen, 2001). Conservation of green manure strips may provide a refuge for soil-borne fungal entomopathogens comparable to the benefits provided of flower strips or beetle banks within fields for arthropod natural enemies (Griffiths et al., 2008). Reduced soil disturbance has been shown to benefit below- ground communities of entomopathogens (Bing and Lewis, 1993; Hummel et al., 2002). However, little is known about the effects of permanent habitats within the cropping system on the populations of fungal entomopathogens.

In the present study, we investigated the spatio-temporal abundance and distribution of fungal entomopathogens in the soil environment and as natural infections in aboveground arthropod hosts in a single agroecosystem. The investigations were carried out within a vegetable cropping system including one conventional and two organic farming practices. Both organic farming systems included green manures, and in one of the systems strips of green manure were maintained between crop rows in the following season. The specific aims were: (1) to evaluate whether the organic farming systems, including the conserved strips of green manure, harbored different soil-borne communities of fungal entomopathogens than the conventionally farmed system, (2) to investigate the spatio-temporal abundance and distribution of fungal entomopathogens in the aboveground arthropod host communities and relate this to the farming practice, and (3) to clarify if the composition of belowground communities of fungal entomopathogens reflected infections of arthropods aboveground.

\section{Materials and methods}

\subsection{Design of the cropping system}

The field site was the experimental cropping system 'VegQure' located at a research farm in Årslev $\left(10^{\circ} 27^{\prime} \mathrm{E}, 55^{\circ} 18^{\prime} \mathrm{N}\right)$, Denmark. The soil of the cropping system is characterized as a sandy loam Agrudalf soil (Thorup-Kristensen et al., 2009). White cabbage and carrots were grown as a part of a vegetable crop rotation system, cabbage always followed rye and carrots followed oat. The experiment consisted of three replicated fields $(80 \mathrm{~m} \times 150 \mathrm{~m}$ each) oriented North-South ( $75 \mathrm{~m}$ between fields). Each field contained four experimental farming systems, and each system included eight plots. Each experimental plot had the dimensions $10 \mathrm{~m} \times 12.5 \mathrm{~m}$. The present study included three of the four experimental farming systems: (1) a conventional system (C1), (2) an organic system with green manure ( 02 ), and (3) an organic system comparable to $\mathrm{O} 2$, but conserved strips of green manure alternated with vegetable crop rows (03) (see Table 1 for details). In $\mathrm{C} 1$ and 02 , each plot contained 21 crop rows while 03 contained 14 crop rows as every third row consisted of the conserved strip of green manure.

\subsection{Collection of soil samples and isolation of fungi}

Soil samples were collected in May 2006-2008 before the crops were planted, and in September 2007 and 2008 when vegetables

Table 1

Main management practices of the three experimental farming systems.

\begin{tabular}{|c|c|c|c|}
\hline \multirow[t]{2}{*}{ Treatment } & \multicolumn{3}{|l|}{ Farming system } \\
\hline & $\begin{array}{l}\text { Conventional } \\
\text { (C1) }\end{array}$ & Organic (02) & Organic (03) \\
\hline $\begin{array}{l}\text { Undersowing } \\
\text { Soil managemen }\end{array}$ & - & Green manure & Green manure \\
\hline Ploughing & November & March & - \\
\hline Rotovation $^{\mathrm{a}}$ & - & - & November \\
\hline Fertilizer $^{\mathrm{b}}$ & $\begin{array}{l}\text { NPK } \\
149 \mathrm{~kg} \mathrm{~N} \mathrm{ha}^{-1}\end{array}$ & $\begin{array}{l}\text { Pig slurry } \\
28 \mathrm{~kg} \mathrm{~N} \mathrm{ha}^{-1}\end{array}$ & $\begin{array}{l}\text { Pig slurry } \\
28 \mathrm{~kg} \mathrm{~N} \mathrm{ha}^{-1}\end{array}$ \\
\hline
\end{tabular}

a Green manure was sown across the whole area of the plot. In November most of it was incorporated into the soil, leaving rows of green manure alternating for every two crop rows.

$\mathrm{b}$ Average fertilization per season. 
were fully grown. One soil sample consisted of three cylindrical soil cores (4.5 cm diameter) taken to a depth of $10 \mathrm{~cm}$ and 5 $7 \mathrm{~cm}$ apart along a straight line, and afterward pooled in a polyethylene bag.

At the beginning of the experiment in May 2006, four such soil samples were collected from each of the 96 experimental plots covering all experimental fields to initially characterize the entire area, yielding 384 samples in total. In early June 2006, 97 soil samples were collected from the hedgerows bordering the experimental field to assess the diversity of fungal entomopathogens in the immediate non-agricultural surroundings. In 2007 and 2008, soil samples were collected from the experimental plots grown with cabbage and carrots (see Table 2). Fifteen soil samples were collected per plot, five soil samples adjacent to each of three crop rows in $\mathrm{C} 1$ and $\mathrm{O} 2$. In $\mathrm{O} 3$, five soil samples were taken at the edge of each of three conserved strips of green manure. Over 2 years, 1080 soil samples in total were collected and processed.

All bags of soil were stored at $5{ }^{\circ} \mathrm{C}$ for 4 months on average until processing. Fungal entomopathogens were isolated using larvae of the wax moth Galleria mellonella L. (Lepidoptera: Pyralidae) as bait insects applying the methodology described by Meyling and Eilenberg (2006). Ten larvae were used to bait each soil sample from the field and eight larvae were used in each soil sample from the hedgerow. Each soil sample was baited for four weeks and incubated in the dark in a climate controlled room at $21( \pm 1)^{\circ} \mathrm{C}$. Once a week soil samples were inspected, dead larvae were removed and rinsed with demineralized water and incubated under humid conditions to encourage fungal growth. Emerging fungi were identified to species in the broad sense by morphological characteristics using dissection microscope $(\times 40)$ and light microscopy $(\times 400)$. In the present study, this applies to $B$. bassiana and M. anisopliae which both are defined in the broad sense (sensu lato) throughout.

\subsection{Collection of mycosed cadavers in the field}

The soil surface in the cabbage plots was systematically searched for arthropod cadavers showing external signs of fungal infections. Once a month from May to September (2007 and 2008), three transects of $10 \mathrm{~m} \times 0.25 \mathrm{~m}$ per plot were searched by the same person, checking each dead arthropod recovered. Transects in three conserved strips of green manure in $\mathrm{O} 3$ were searched per plot in all months. In August and September 2007, and in July, August and September 2008, three transects of similar dimensions between rows of cabbage were searched per plot in $\mathrm{C} 1$ and 02 . Thus nine transects were searched at each occasion per farming system in the three replicated experimental fields. In September 2007 and 2008, three additional transects were searched per plot in $\mathrm{C} 1$ and $\mathrm{O} 21$ week later between other rows than the previous week. Arthropod cadavers were placed separately in $30 \mathrm{ml}$ medicine cups which were sealed with a lid. In the laboratory, the fungal infection of each host was identified. The host was identified as detailed to taxon as possible. The length of each

Table 2

Number of soil samples in the three replicated experimental fields of the three farming systems collected at four occasions over two seasons.

\begin{tabular}{|c|c|c|c|c|c|c|c|}
\hline \multirow[b]{3}{*}{ Date/Crop } & \multicolumn{6}{|c|}{ Farming system } & \multirow{3}{*}{$\begin{array}{l}\text { Total } \\
(n)\end{array}$} \\
\hline & \multicolumn{2}{|l|}{$\mathrm{C} 1$} & \multicolumn{2}{|l|}{$\mathrm{O} 2$} & \multicolumn{2}{|l|}{$\mathrm{O} 3$} & \\
\hline & Cabbage & Carrots & Cabbage & Carrots & Cabbage & Carrots & \\
\hline May 2007 & 45 & 45 & 45 & 45 & 45 & 45 & 270 \\
\hline $\begin{array}{c}\text { September } \\
2007\end{array}$ & 45 & 45 & 45 & 45 & 45 & 45 & 270 \\
\hline May 2008 & 45 & 45 & 45 & 45 & 45 & 45 & 270 \\
\hline $\begin{array}{c}\text { September } \\
2008\end{array}$ & 45 & 45 & 45 & 45 & 45 & 45 & 270 \\
\hline
\end{tabular}

cadaver was measured, and the infected hosts were assigned to one of four functional feeding groups; herbivore $(\mathrm{H})$, nectar-feeder $(\mathrm{N})$, predator $(\mathrm{Pr})$, or parasitoid $(\mathrm{Pa})$. If this assignment was not possible, functional group was defined as unknown $(U)$.

\subsection{Data analysis}

Data were analyzed by mixed models in PROC MIXED in SAS with random effect of experimental field adjusting degrees of freedom by Satterthwaite formulae (Littell et al., 1996). When possible, models tested for effects of year, month, crop, and farming system, including all potential interactions on respective response variables. Non-significant $(P>0.10)$ higher order interactions were successively removed from the models until final models were obtained. A mixed model was used to analyze the proportion of soil samples positive for M. anisopliae in each experimental plot $(x)$ 15) calculated for data collected in 2007 and 2008 including storage time (days) of soil samples as a covariate. These proportions were arc-sin transformed prior to analysis. Cadaver numbers were analyzed by a mixed model for collections in 2008 only. The number of cadavers $(+1)$ recovered per experimental plot was logtransformed prior to analysis. The model tested for effects of farming system and month, including their interaction. Cadaver sizes were log-transformed and analyzed for effects of farming system, the fungal taxon infecting them and the interaction of the two factors. In some cases pairs of data were analyzed by standard parametric and non-parametric tests.

\section{Results}

\subsection{Belowground distribution of fungal entomopathogens}

The initial characterization of the soil-borne community of fungal entomopathogens in 2006 showed that M. anisopliae was dominant in the agricultural field while it was rarely detected in the hedgerow soil (Table 3 ). The most frequent fungal taxon in the hedgerow was $B$. bassiana while this fungus was only detected in $9.6 \%$ of the soil samples from the agricultural field. Isaria farinosa (Holmsk.) Fr. and Isaria fumosorosea Wize were mostly isolated from the hedgerow soil. Metarhizium flavoviride Gams and Rozsypal was found in $1.3 \%$ of the samples from agricultural field soil while it was not detected in any soil samples from the hedgerow.

In 2007 and 2008 M. anisopliae continued to be the most frequent fungus in soil samples from each of the three different farming systems, conventional $(\mathrm{C} 1 ; 47.6-78.9 \%)$, organic $(\mathrm{O} 2 ; 50-$ $77.8 \%)$ and organic with conservation of green manure strips (03; 37.8-62.2\%). In both 2007 and 2008, B. bassiana occurred at frequencies between $11.1 \%$ and $16.7 \%$ per system. None of the frequencies of $B$. bassiana differed significantly among farming systems $\left(\chi^{2}\right.$-test; $\left.\mathrm{df}=1 ; P>0.05\right)$. Species richness in the three

Table 3

Initial frequency of occurrence (\%) of selected fungal entomopathogens in soil samples from the area of the experimental fields (three replicated fields together) and surrounding hedgerows in May and June 2006. Within each row, differences between frequencies from field and hedgerow were tested with $\chi^{2}$ statistics unless $25 \%$ of predicted values were less than 5 .

\begin{tabular}{lllll}
\hline Fungus $^{\mathrm{a}}$ & $\begin{array}{l}\text { Field } \\
(n=384)\end{array}$ & $\begin{array}{l}\text { Hedgerow } \\
(n=97)\end{array}$ & $\chi^{2}$ & $P$ \\
\hline $\begin{array}{c}\text { Metarhizium } \\
\text { anisopliae }\end{array}$ & 56.5 & 3.1 & 89.03 & $<0.0001$ \\
$\begin{array}{l}\text { Beauveria bassiana } \\
\text { Isaria farinosa }\end{array}$ & 9.6 & 53.6 & 99.30 & $<0.0001$ \\
Isaria fumosorosea & 1.6 & 10.3 & $\mathrm{~N} / \mathrm{A}$ & $\mathrm{N} / \mathrm{A}$ \\
\hline
\end{tabular}

${ }^{a}$ Fungi were identified based on morphological characters. 
systems ranged from five fungal taxa in $\mathrm{C} 1$, six taxa in $\mathrm{O} 2$, and seven taxa in O3. Besides M. anisopliae and B. bassiana, taxa included M. flavoviride which was found in $2.2-6.7 \%$ of the soil samples in $\mathrm{C} 1$, in $3.3-5.6 \%$ of the samples in 02 , and in $4.4-6.7 \%$ of the samples in O3. In all three systems I. fumosorosea was isolated at frequencies of $1.1-2.2 \%$, while $I$. farinosa was found at frequencies of $3.3-5.6 \%$ in $\mathrm{C} 1,1.1-2.2 \%$ in 02 , and $2.2-6.7 \%$ in 03 . Hirsutella nodulosa Petch was only found in the two organic systems in 2008 , but at low frequencies ranging from $2.2 \%$ of the soil samples in 03 in May 2008 to $1.1 \%$ of the samples in $\mathrm{O} 2$ in September 2008. Conidiobolus coronatus (Constantin) Batko (Entomophthoramycotina: Entomophthorales) was also found, although only in $\mathrm{O} 3$ (in $2.2 \%$ of the samples) in May 2008.

No interactions were significantly explaining transformed proportions of $M$. anisopliae in the experimental plots $(P>0.10)$. The final model thus showed that the occurrence of $M$. anisopliae in the plots could be explained by the year of sampling $\left(F_{1,63.4}=9.68 ; P=0.0028\right.$; proportions being higher in 2007 than in 2008; Fig. 1$)$ and farming system $\left(F_{2,63}=4.07 ; P=0.0217\right)$. Neither month in year $\left(F_{1,63.3}=0.79 ; P=0.3788\right)$, crop in the plot $\left(F_{1,63}=0.13 ; \quad P=0.7219\right)$, nor storage time of soil samples $\left(F_{1,64.3}=0.69 ; P=0.4087\right)$ significantly explained proportions of $M$. anisopliae. Comparisons between farming systems showed that a significantly higher proportion of $M$. anisopliae was found in $\mathrm{O} 2$ compared to $\mathrm{O} 3$ (Tukey-Kramer Adjustment: $P=0.0183$; Fig. 1). However, no difference in occurrence of $M$. anisopliae was found between the conventional $\mathrm{C} 1$ and organic $\mathrm{O} 2$ systems (Tukey-Kramer Adjustment: $P=0.6294$ ) or between $C 1$ and the strip of green manure in organic system 03 (Tukey-Kramer Adjustment: $P=0.1556)$.

\subsection{Aboveground fungal infections in arthropods}

Mycosed cadavers with fungal entomopathogens were mostly found in the latter part of both 2007 and 2008 (Fig. 2a and b). Analysis of these data was conducted for season 2008 by a mixed model with experimental field as random factor. There were significant effects of farming system $\left(F_{2,22}=5.66 ; P=0.0104\right)$, month $\left(F_{3,22}=26.14 ; \quad P<0.0001\right)$ and their interaction $\left(F_{6,22}=6.47\right.$; $P=0.0005)$. Post hoc tests were therefore performed for each farming system per month. Within individual months, differences among farming systems were only found in August 2008, with significantly more mycosed cadavers in the conventional system (C1) than in the organic system (O2) (Tukey-Kramer Adjustment: $P=0.0105)$ and in September 2008, where more cadavers were collected in $\mathrm{C} 1$ than in the conserved strip of green manure (O3) (Tukey-Kramer Adjustment: $P=0.0095$; Fig. $2 b)$. The remaining

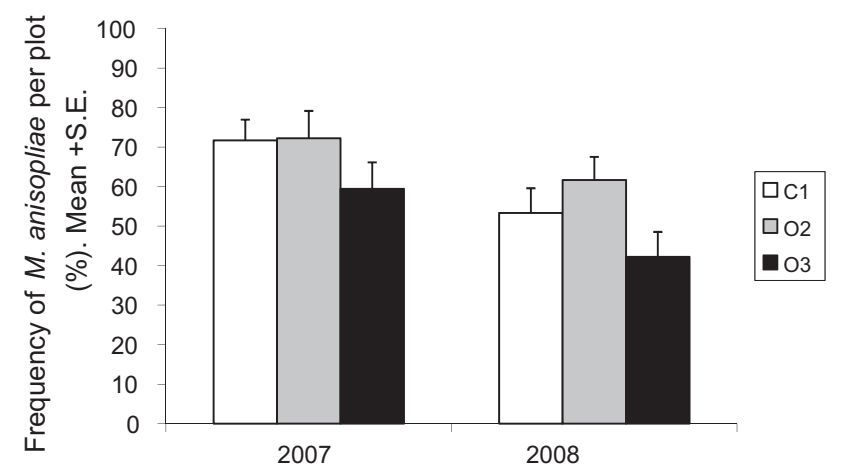

Fig. 1. Mean frequencies (+S.E.) of M. anisopliae in soil samples from experimental plots under three different farming practices ( $n=180$ per farming system per year); C1 (conventional farming), $\mathrm{O} 2$ (organic farming), and $\mathrm{O} 3$ (conserved strips of green manure in organic farming) over 2 years.
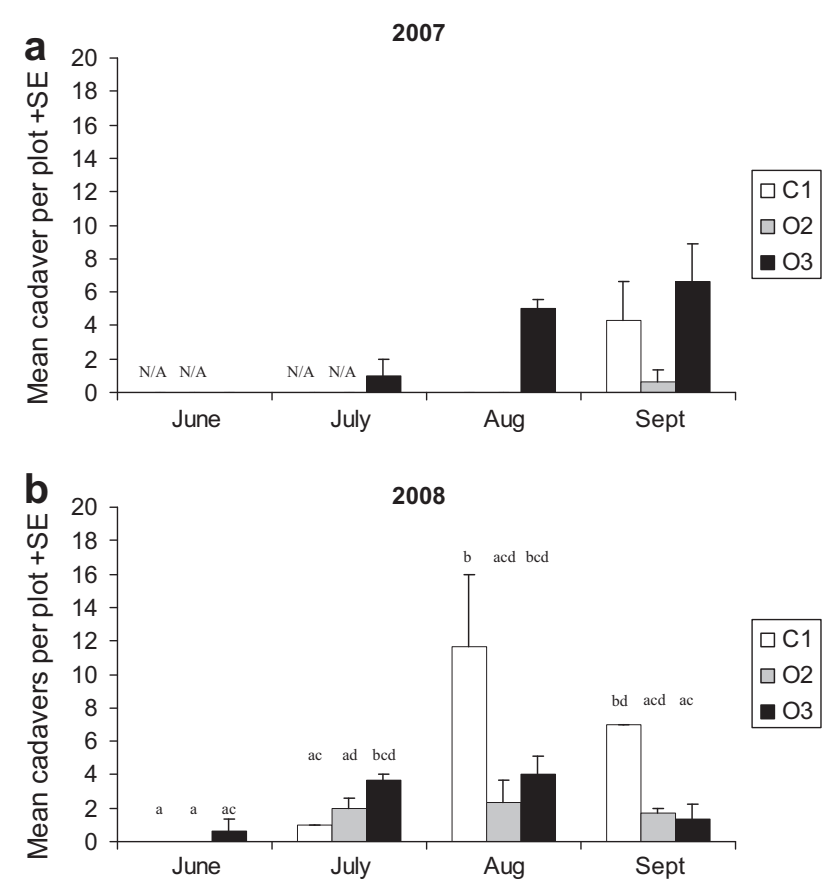

Fig. 2. Observed means (+S.E.) of mycosed cadavers on the soil surface of experimental plots under three different farming practices; $\mathrm{C} 1$ (conventional farming), $\mathrm{O} 2$ (organic farming), and $\mathrm{O} 3$ (conserved strips of green manure in organic farming) in two seasons ( $n=3$ per farming practice per year). Different letters above bars indicate significant differences in cadaver numbers in 2008 (b).

differences were found among farming systems in different months (Fig. 2b). Additional sampling of cadavers in September 2007 and 2008 in $\mathrm{C} 1$ and $\mathrm{O} 2$ revealed significantly more cadavers in $\mathrm{C} 1$ than in $\mathrm{O} 2$ at comparable search efforts (Table 4).

Four taxa, B. bassiana, I. farinosa, and M. flavoviride and Gibellula spp., were found on mycosed cadavers, the latter taxon only on spiders (Aranae). In total, 212 mycosed arthropods were recorded during the study period. In August and September 2007, the mean size $( \pm$ SE) of 49 mycosed arthropod cadavers collected was $3.7 \mathrm{~mm}$ $( \pm 0.3 \mathrm{~mm})$ (range: $0.9-13.3 \mathrm{~mm}$ ). Size distributions of cadavers (Tables 5 and 6 ) were not explained by farming system $\left(F_{2,38.7}=1.00 ; P=0.3767\right)$, but by fungal taxon $\left(F_{3,38.1}=5.29\right.$; $P=0.0038)$ and host functional group $\left(F_{4,38.2}=6.91 ; P=0.0003\right)$. Cadavers mycosed by $B$. bassiana were significantly larger than spider cadavers with Gibellula spp. (Table 5). Mycosed arthropod hosts of unknown functional groups were significantly smaller than

Table 4

Number of mycosed cadavers recovered during additional samplings in September 2007 and 2008 in between rows of white cabbage in conventional (C1) and organic (O2) farming systems. For each year pairwise comparisons were made by $\chi^{2}$ tests using Yates' correction for one degree of freedom.

\begin{tabular}{llrll}
\hline & $\mathrm{C} 1$ & $\mathrm{O} 2$ & $\chi^{2}$ & $P$ \\
\hline September 2007 & 14 & 1 & 9.6 & $<0.01$ \\
September 2008 & 24 & 11 & 4.114 & $<0.05$ \\
\hline
\end{tabular}

Table 5

Numbers and size distributions (mean + S.E.) of mycosed cadavers among fungal taxa in all three experimental systems in August and September 2007. Sizes followed by different letters are significantly different.

\begin{tabular}{lllll}
\hline & B. bassiana & Gibellula spp. & I. farinosa & M. flavoviride \\
\hline$n$ & 25 & 22 & 1 & 1 \\
Size (+S.E.) & $4.1 \mathrm{~mm}+0.5$ a & $3.2 \mathrm{~mm}+0.2 \mathrm{~b}$ & $1.9 \mathrm{~mm}$ ab & $5.2 \mathrm{~mm}$ ab \\
\hline
\end{tabular}


Table 6

Numbers and size distributions (mean + S.E.) of mycosed cadavers among host functional groups in all three experimental systems in August and September 2007. Sizes followed by different letters are significantly different.

\begin{tabular}{|c|c|c|c|c|c|}
\hline & Herbivore & Parasitoid & Predator & Nectar-feeder & Unknown \\
\hline$n$ & 8 & 2 & 33 & 1 & 5 \\
\hline Size (+S.E.) & $3.9 \mathrm{~mm}+0.6 \mathrm{a}$ & $3.2 \mathrm{~mm}+0.7 \mathrm{ab}$ & $3.9 \mathrm{~mm}+0.4 \mathrm{a}$ & $4.1 \mathrm{~mm}$ ab & $1.6 \mathrm{~mm}+0.2 \mathrm{~b}$ \\
\hline
\end{tabular}

predator and herbivores (Table 6). None of the possible interactions were found to be significant.

Collections at three dates in all the experimental fields in 2008 yielded 104 mycosed cadavers with mean size $( \pm S E)$ of $4.1 \mathrm{~mm}$ $( \pm 0.3 \mathrm{~mm})$ (range: $1.3-23.6 \mathrm{~mm})$. Analysis with a mixed model as described above showed that cadaver size distributions in 2008 were explained by interactions between farming system and fungal taxon $\left(F_{4,85}=2.85 ; P=0.0286\right.$; Table 7$)$ and between farming system and host functional group $\left(F_{5,85}=4.39 ; P=0.0013\right.$; Table 8$)$. No other interactions were significant. The largest cadaver $(23.6 \mathrm{~mm})$ was a noctuid moth mycosed by $B$. bassiana found in the organic system $\mathrm{O} 2$ (Table 8). Overall, mean sizes of cadavers in the plots were not different between the two years of collection ( $z$-test: $z=1.667 ; P>0.05$ ).

Seventy-one cadavers were collected in 2007 in total. Of these, $63 \%(n=45)$ were predators, $4 \%(n=3)$ parasitoids, $17 \%(n=12)$ herbivores and $4 \%(n=3)$ nectar-feeders. Eight mycosed cadavers (11\%) could not be identified to either of the functional groups. Of the total of 141 mycosed cadavers recovered from the experimental plots during all collections in 2008, $47 \%(n=66)$ were predators, $8 \%(n=11)$ were parasitoids, $28 \%(n=39)$ were herbivores while nectar-feeders constituted $4 \%(n=6)$. Nineteen $(13 \%)$ of the cadavers were not possible to assign to functional group. The herbivores were dominated by coleopterans (7/12 in 2007 and 35/39 in 2008), mostly cabbage weevils (Ceutorhynchus pallidactylus Marsham). The remaining herbivores were hemipterans. In 2008, eight of the 24 cabbage weevils were infected by $M$. flavoviride while this fungus was recorded from a single cereal leaf beetle, Oulema melanopus (L.), in 2007. Of the predators (totally 45 in 2007 and 66 in 2008), 28 (62\%) and 24 (36\%) were money spiders (Linyphiidae) in 2007 and 2008, respectively. Of these all were infected by Gibellula spp. except one in 2007 which was infected by B. bassiana. Sixteen (36\%) and 35 (53\%) of the predators were staphylinid beetles in 2007 and 2008, respectively, all of which were infected by B. bassiana. The remaining mycosed predators were seven spot ladybirds (Coccinella septempunctata L.; one in 2007 and three in 2008), a flower bug, Anthocoris nemorum (L.), and an unidentified ant, both in 2008. In 2007, all three mycosed parasitoids were Trybliographa rapae (Westwood) (Hymenoptera: Figitidae) while this species constituted $45 \%$ (5/11) of mycosed parasitoids in 2008. The frequencies of cadavers in the five different functional categories were not significantly different between the 2 years $\left(\chi^{2}=5.8439\right.$; $\mathrm{df}=4 ; P=0.2111$ ).

Comparable below- and aboveground abundance and distribution of hypocrealean fungal entomopathogens in 2007 and 2008 were found in the experimental agricultural field, but there were clear differences between below- and aboveground environments (Fig. 3). M. anisopliae and I. fumosorosea were only detected in the soil environment, while B. bassiana, I. farinosa, and M. flavoviride were recovered both below- and aboveground. Only aboveground occurrence of Gibelulla spp. was documented.

\section{Discussion}

Our results document that communities of hypocrealean fungal entomopathogens were differently structured below- and aboveground in the investigated agroecosystem. Specifically, M. anisopliae dominated belowground while $B$. bassiana was most often recovered among mycosed cadavers aboveground thus indicating that M. anisopliae is not involved in direct below- and aboveground interactions in this agricultural field. Our data support the view that $M$. anisopliae predominantly cycles belowground while B. bassiana occurs both below- and aboveground in temperate agroecosystems (Meyling and Eilenberg, 2007).

Overall belowground diversity of fungal entomopathogens and frequencies of occurrence of $M$. anisopliae were similar in agricultural field soils of experimental conventional (C1) and organic (O2) systems. Belowground communities of fungal entomopathogens have been reported to be similar between conventional and organic farming practices (Goble et al., 2010; Jabbour and Barbercheck, 2009) although Klingen et al. (2002) found higher occurrences of some fungal entomopathogens in soil samples collected at organic vs. conventional fields. Conventional farming practices

Table 7

Numbers and size distributions (mean \pm S.E.) of mycosed cadavers among fungal taxa in each of the three experimental systems in July, August and September 2008 .

\begin{tabular}{|c|c|c|c|c|c|c|c|c|c|c|c|c|}
\hline \multirow[b]{2}{*}{ Fungus $^{\mathrm{a}}$} & \multicolumn{4}{|c|}{ C1 (Conventional farming) } & \multicolumn{4}{|c|}{$\mathrm{O} 2$ (Organic farming) } & \multicolumn{4}{|c|}{ O3 (Strip of green manure in organic farming) } \\
\hline & B. $b$. & Gib. & I. far. & M. fla. & B. $b$. & Gib. & I. far. & M. fla. & B. b. & Gib. & I. far. & M. fla. \\
\hline$n$ & 39 & 3 & 13 & 4 & 11 & 5 & 0 & 2 & 16 & 10 & 0 & 1 \\
\hline Size & $4.2 \mathrm{~mm}$ & $4.7 \mathrm{~mm}$ & $3.5 \mathrm{~mm}$ & $3.4 \mathrm{~mm}$ & $5.1 \mathrm{~mm}$ & $4.3 \mathrm{~mm}$ & - & $3.3 \mathrm{~mm}$ & $4.9 \mathrm{~mm}$ & $3.1 \mathrm{~mm}$ & - & $3.6 \mathrm{~mm}$ \\
\hline S.E. & \pm 0.3 & \pm 1.1 & \pm 0.4 & \pm 0.2 & \pm 1.9 & \pm 0.5 & - & \pm 0.4 & \pm 0.8 & \pm 0.2 & - & - \\
\hline
\end{tabular}

${ }^{a}$ Fungal taxa include B. b., Beavueria bassiana; Gib., Gibellula spp.; I. far., Isaria farinosa; M. fla., Metarhizium flavoviride.

Table 8

Numbers and size distributions (mean \pm S.E.) of mycosed cadavers among host functional groups in each of the three experimental systems in July, August and September 2008 .

\begin{tabular}{|c|c|c|c|c|c|c|c|c|c|c|c|c|c|c|c|}
\hline \multirow[b]{2}{*}{ Func. $^{a}$} & \multicolumn{5}{|c|}{ C1 (Conventional farming) } & \multicolumn{5}{|c|}{ O2 (Organic farming) } & \multicolumn{5}{|c|}{ O3 (Strip of green manure in organic farming) } \\
\hline & $\mathrm{H}$ & $\mathrm{Pa}$ & $\operatorname{Pr}$ & $\mathrm{N}$ & $\mathrm{U}$ & $\mathrm{H}$ & $\mathrm{Pa}$ & $\operatorname{Pr}$ & $\mathrm{N}$ & $\mathrm{U}$ & $\mathrm{H}$ & $\mathrm{Pa}$ & $\operatorname{Pr}$ & $\mathrm{N}$ & $\mathrm{U}$ \\
\hline$n$ & 20 & 3 & 23 & 0 & 13 & 6 & 3 & 8 & 1 & 0 & 4 & 0 & 18 & 2 & 3 \\
\hline Size & $3.6 \mathrm{~mm}$ & $3.9 \mathrm{~mm}$ & $4.7 \mathrm{~mm}$ & - & $3.3 \mathrm{~mm}$ & $3.2 \mathrm{~mm}$ & $3.4 \mathrm{~mm}$ & $3.9 \mathrm{~mm}$ & $23.6 \mathrm{~mm}$ & - & $3.1 \mathrm{~mm}$ & - & $4.5 \mathrm{~mm}$ & $5.3 \mathrm{~mm}$ & $2.5 \mathrm{~mm}$ \\
\hline S.E. & \pm 0.2 & \pm 0.5 & \pm 0.5 & - & \pm 0.3 & \pm 0.1 & \pm 0.8 & \pm 0.4 & - & - & \pm 0.3 & - & \pm 0.7 & \pm 0.9 & \pm 1.1 \\
\hline
\end{tabular}

${ }^{a}$ Func. = functional group. These include H, herbivore; Pa, parasitoid; Pr, predator; N, nectar-feeder; U, unknown. 
a
M. anisopliae $\square$ B. bassiana $\square$ l. farinosa 曰I. fumosorosea $\square$ M. flavoviride $\square$ Gibelulla spp.

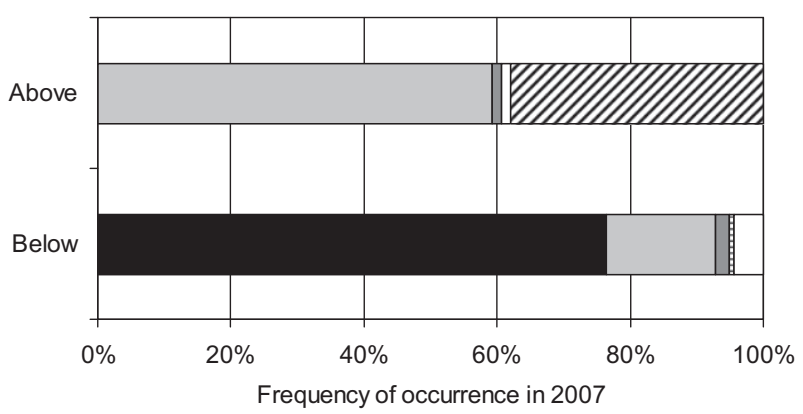

b

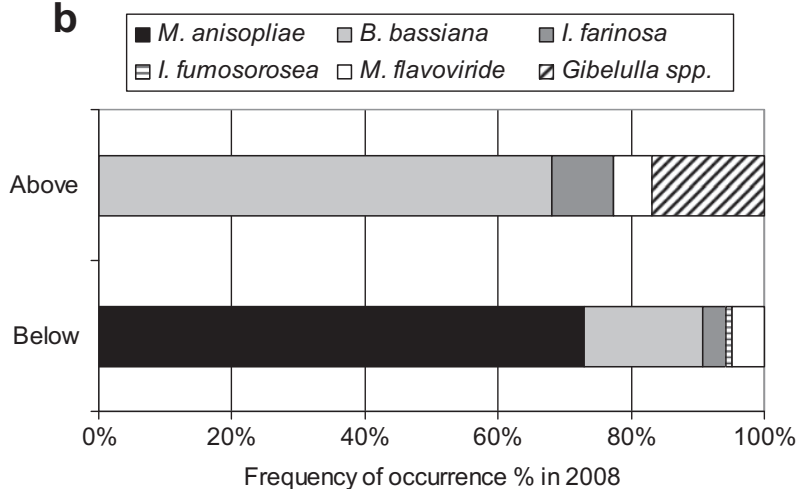

Fig. 3. Frequencies of different fungal entomopathogens among all mycosed cadavers recovered aboveground (above; $n=71$ in 2007, 3a, $n=141$ in 2008, 3b) and among all fungi recovered belowground by baiting soil samples with Galleria mellonella larvae (below; $n=491$ in 2007, 3a, $n=400$ in 2008, 3b).

often include use of chemical pesticides. Specifically M. anisopliae is considered to be tolerant to pesticides (Klingen and Haukeland, 2006), and presumably pesticides do not have detrimental effects on this fungus in soils.

Structural habitat architecture and disturbance levels may be more important than conventional and organic practices for composition of belowground communities of fungal entomopathogens. Most taxa were isolated from the soil of the strips of green manure in $\mathrm{O} 3$ and the abundance of $M$. anisopliae in the conserved strips was lower than in the soil of the otherwise similarly farmed $\mathrm{O}$. This indicates that other conditions prevailed in the soil of the conserved strip than in the soil of the agricultural field. Reduced soil disturbance was reported to be associated with decreased frequencies of M. anisopliae in soil samples by Jabbour and Barbercheck (2009), who suggested that higher organic matter contents of low tilled soils would not favor M. anisopliae due to antagonistic activity of other soil organisms. Such belowground interactions may also occur in the conserved strip of green manure in $\mathrm{O} 3$ explaining reductions in $M$. anisopliae occurrence.

Spatio-temporal variation in abundance and distribution of fungal entomopathogens was observed aboveground while no significant variation during the season was evident belowground. Aboveground, fungal entomopathogens are inactivated within days or weeks by solar radiation (Daoust and Pereira, 1986a; Inglis et al., 2001) and rainfall (Daoust and Pereira, 1986b). In contrast, the soil environment provides a stabile habitat for high persistence of fungal spores thus buffering population fluctuations (van der Putten et al., 2001). Our results further indicate that fungal infections aboveground were detected earlier in the conserved strip of green manure in $\mathrm{O} 3$ than in between crop rows in $\mathrm{C} 1$ and $\mathrm{O} 2$. A permanent plant cover is expected to provide a refuge for the arthropod community in the field (Griffiths et al., 2008) and may therefore also provide hosts for fungal entomopathogens early in the season. In addition, most mycosed cadavers were recovered from the conventionally farmed system $\mathrm{C} 1$. Activity-density estimates of ground dwelling arthropods in the same plots did not indicate higher abundance of these in $\mathrm{C} 1$ compared to the organic systems (Navntoft, unpublished data) thus the higher occurrence of infected hosts may be attributed to other factors than host density. In the conventional system, the crop canopy of white cabbages had closed to the greatest extend late in the growth season when most cadavers were collected (Meyling, pers. obs.). Microclimatic conditions such as humidity could favor infections under the crop canopy resulting in higher occurrence in the conventional system. Indeed, Yaginuma (2007) showed correlation between rainfall intensity and cadaver occurrence. Persistence of mycosed cadavers on the soil surface after host death remains unknown, but conidia on sporulating insect cadavers can be entirely removed after 2 weeks under field conditions (Daoust and Pereira, 1986b).

Few studies have evaluated spatio-temporal abundance and distribution of mycosed cadavers. In an apple orchard in Japan, $B$. bassiana dominated aboveground $(87.7 \%$ out of 10,411 cadavers over 6 years of collections) with cadaver numbers mostly peaking in September (Yaginuma, 2007). Furthermore, low occurrences of M. anisopliae ( $1.0 \%$ of all cadavers) were documented, thus supporting our data indicating that $M$. anisopliae is rare as infections in aboveground hosts in temperate regions. Likewise, Steenberg et al. (1995) reported of occurrences of $M$. anisopliae infections in predatory ground and rove beetles of $1.6-2.0 \%$. A survey of mycosed cadavers in Poland revealed 37 taxa of fungal entomopathogens in forest and meadow habitats (Sosnowska et al., 2004). In these habitats, $B$. bassiana was also found to be most common among the mycosed cadavers while no infections by M. anisopliae were reported (Sosnowska et al., 2004).

The largest proportion of mycosed cadavers in the present study was identified as predators, predominantly staphylinid beetles. This proportion among functional host groups appears representative as cadavers of predators were no larger than those from other groups and therefore unlikely to be more conspicuous. Predatory insects often exhibit low susceptibility to fungal entomopathogens in laboratory bioassays (Dunkel and Jaronski, 2003; Riedel and Steenberg, 1998; Traugott et al., 2005), but other studies have shown that predatory beetles may succumb to fungal infections in the field (Steenberg et al., 1995; Yaginuma, 2007). Among predators, we recorded frequent infections in spiders by Gibellula spp. in the strip of green manure in $\mathrm{O3}$ (50\% in 2007 ; $85 \%$ in 2008). Sosnowska et al. (2004) also reported that Gibellula spp. co-dominated with $B$. bassiana in aboveground arthropods of grasslands. It is so far unknown how fungal entomopathogens affect spider populations, but Gibellula spp. may be a significant mortality factor to spiders. Indeed, mortality caused by fungal infections may contribute significantly to population regulation of predatory arthropods in managed ecosystems. Potentially such mortality factors may negatively affect natural regulation of pests by predatory arthropods, but future studies must evaluate how fungal entomopathogens conflict with effects of predators. Recent studies suggest that belowground entomopathogens and predators aboveground can complement each other in regulation of pests (Ramirez and Snyder, 2009; Crowder et al., 2010).

In conclusion, observations of spatio-temporal abundance and distribution of fungal entomopathogens have provided new insights to the population dynamics and ecological niches of specific fungal taxa. Belowground, M. anisopliae was dominating the agricultural fields but conservation of strips of green manure reduced the frequency of $M$. anisopliae while other fungal taxa seemed to be added to the belowground community. Future conservation biological control strategies targeting $M$. anisopliae in the soil for control of pests attacking plant parts aboveground may therefore be 
unsuccessful and should only aim at controlling soil dwelling pests. In contrast, below- and aboveground interactions involving B. bassiana and $M$. flavoviride were indicated in the agroecosystem. Thus these fungal entomopathogens are expected to contribute to natural regulation of aboveground arthropod hosts.

\section{Acknowledgments}

Christina Wolsted and Karina L. Madsen provided technical assistance in the field and laboratory. We thank Christian Ritz for statistical advice. This research was funded by the Danish DARCOF III program for research in organic farming.

\section{References}

Axelsen, J.A., Kristensen, K.T., 2001. Collembola and mites in plots fertilised with different types if green manure. Pedobiologia 44, 556-566.

Bidochka, M.J., Kasperski, J.E., Wild, G.A.M., 1998. Occurrence of the entomopathogenic fungi Metarhizium anisopliae and Beauveria bassiana in soils from temperate and near-northern habitats. Canadian Journal of Botany $76,1198-1204$.

Bing, L.A., Lewis, L.C., 1993. Occurrence of the entomopathogen Beauveria bassiand (Balsamo) Vuillemin in different tillage regimes and in Zea mays L. and virulence towards Ostrinia nubialis (Hübner). Agriculture, Ecosystems and Environment 45, 147-156.

Birkhofer, K., Bezemer, T.M., Bloem, J., Bonkowski, M., Christensen, S., Dubois, D. Ekelund, F., Fliessbach, A., Gunst, L., Hedlund, K., Mader, P., Mikola, J., Robin, C., Setala, H., Tatin-Froux, F., van der Putten, W.H., Scheu, S., 2008. Long-term organic farming fosters below and aboveground biota: implications for soil quality, biological control and productivity. Soil Biology and Biochemistry 40, 2297-2308.

Chandler, D., Hay, D., Reid, A.P., 1997. Sampling and occurrence of entomopathogenic fungi and nematodes in UK soils. Applied Soil Ecology 5, 133-141.

Crowder, D.W., Northfield, T.D., Strand, M.R., Snyder, W.E., 2010. Organic agriculture promotes evenness and natural pest control. Nature 466, 109-112.

Daoust, R.A., Pereira, R.M., 1986a. Stability of entomopathogenic fungi Beauveria bassiana and Metarhizium anisopliae on beetle-attracting tubers and cowpea foliage in Brazil. Environmental Entomology 15, 1237-1243.

Daoust, R.A., Pereira, R.M., 1986b. Survival of Beauveria bassiana (Deuteromycetes: Moniliales) conidia on cadavers of cowpea pests stored outdoors and in laboratory in Brazil. Environmental Entomology 15, 642-647.

Dunkel, F.V., Jaronski, S.T., 2003. Development of a bioassay system for the predator, Xylocoris flavipes (Heteroptera: Anthocoridae), and its use in subchronic toxicity/pathogenicity studies of Beauveria bassiana strain GHA. Journal of Economic Entomology 96, 1045-1053.

Goble, T., Dames, J., Hill, P., Moore, S., 2010. The effects of farming system, habitat type and bait type on the isolation of entomopathogenic fungi from citrus soils in the Eastern Cape Province, South Africa. BioControl 55, 399-412.

Griffiths, G.J.K., Holland, J.M., Bailey, A., Thomas, M.B., 2008. Efficacy and economics of shelter habitats for conservation biological control. Biological Control 45 200-209.

Hesketh, H., Roy, H.E., Eilenberg, J., Pell, J.K., Hails, R.S., 2010. Challenges in modelling complexity of fungal entomopathogens in semi-natural populations of insects. BioControl 55, 55-73.

Hummel, R.L., Walgenbach, J.F., Barbercheck, M.E., Kennedy, G.G., Hoyt, G.D. Arellano, C., 2002. Effects of production practices on soil-borne entomopathogens in western North Carolina vegetable systems. Environmental Entomology 31, 84-91.

Inglis, G.D., Goettel, M.S., Butt, T.M., Strasser, H., 2001. Use of hyphomycetous fungi for managing insect pests. In: Butt, T.M., Jackson, C., Magan, N. (Eds.), Fungi as
Biocontrol Agents. Progress, Problems and Potential. CABI Publishing, pp. 2369.

Jabbour, R., Barbercheck, M.E., 2009. Soil management effects on entomopathogenic fungi during the transition to organic agriculture in a feed grain rotation. Biological Control 51, 435-443.

Klingen, I., Haukeland, S., 2006. The soil as a reservoir for natural enemies of pest insects and mites with emphasis on fungi and nematodes. In: Eilenberg, J., Hokkanen, H.M.T. (Eds.), An Ecological and Societal Approach to Biological Control. Springer, Netherlands, pp. 145-211.

Klingen, I., Eilenberg, J., Meadow, R., 2002. Effects of farming system, field margins and bait insect on the occurrence of insect pathogenic fungi in soils. Agriculture Ecosystems and Environment 91, 191-198.

Lammerts van Bueren, E.T., Struik, P.C., Jacobsen, E., 2002. Ecological concepts in organic farming and their consequences for an organic crop ideotype. Netherlands Journal of Agricultural Science 50, 1-26.

Littell, R.C., Milliken, G.A., Storup, W.W., Wolfinger, R.D., 1996. SAS System for Mixed Models. SAS Institute, Cary, NC, USA.

Mäder, P., Fliessbach, A., Dubois, D., Gunst, L., Fried, P., Niggli, U., 2002. Soil fertility and biodiversity in organic farming. Science 296, 1694-1697.

Meyling, N.V., Eilenberg, J., 2006. Occurrence and distribution of soil borne entomopathogenic fungi within a single organic agroecosystem. Agriculture Ecosystems and Environment 113, 336-341.

Meyling, N.V., Eilenberg, J., 2007. Ecology of the entomopathogenic fungi Beauveria bassiana and Metarhizium anisopliae in temperate agroecosystems: potential for conservation biological control. Biological control 43, 145-155.

Meyling, N.V., Lubeck, M., Buckley, E.P., Eilenberg, J., Rehner, S.A., 2009. Community composition, host range and genetic structure of the fungal entomopathogen Beauveria in adjoining agricultural and seminatural habitats. Molecular Ecology $18,1282-1293$.

Ormond, E.L. Thomas, A.P.M., Pugh, PJA., Pell, J.K. Roy, H.E, 2010. A fungal pathogen in time and space. the population dynamics of Beauveria bassiana in a conifer forest. FEMS Microbiology Ecology 74, 146-154.

Ramirez, R.A., Snyder, W.E., 2009. Scared sick? Predator-pathogen facilitation enhances exploitation of a shared resource. Ecology 90, 2832-2839.

Riedel, W., Steenberg, T., 1998. Adult polyphagous coleopterans overwintering in cereal boundaries: winter mortality and susceptibility to the entomopathogenic fungus Beauveria bassiana. BioControl 43, 175-188.

Sosnowska, D., Balazy, S., Prishchepa, L., Mikulskaya, N., 2004. Biodiversity of arthropod pathogens in the Bialowieza forest. Journal of Plant Protection Research 44, 313-321.

Steenberg, T., Langer, V., Esbjerg, P., 1995. Entomopathogenic fungi in predatory beetles (Col: Carabidae and Staphylinidae) from agricultural fields. Entomophaga 40, 77-85.

Thorup-Kristensen, K., Cortasa, M.S., Loges, R., 2009. Winter wheat roots grow twice as deep as spring wheat roots, is this important for $\mathrm{N}$ uptake and $\mathrm{N}$ leaching losses? Plant and Soil 322, 101-114.

Traugott, M., Weissteiner, S., Strasser, H., 2005. Effects of the entomopathogenic fungus Beauveria brongniartii on the non-target predator Poecilus versicolor (Coleoptera : Carabidae). Biological Control 33, 107-112.

van der Putten, W.H., Vet, L.E.M., Harvey, J.A., Wickers, F.L., 2001. Linking above- and belowground multitrophic interactions of plants, herbivores, pathogens, and their antagonists. Trends in Ecology and Evolution 16, 547-554.

van der Putten, W.H., Bardgett, R.D., de Ruiter, P.C., Hol, W.H.G., Meyer, K.M. Bezemer, T.M., Bradford, M.A., Christensen, S., Eppinga, M.B., Fukami, T. Hemerik, L., Molofsky, J., Schadler, M., Scherber, C., Strauss, S.Y., Vos, M., Wardle, D.A., 2009. Empirical and theoretical challenges in abovegroundbelowground ecology. Oecologia 161, 1-14.

Vega, F.E., Goettel, M.S., Blackwell, M., Chandler, D., Jackson, M.A., Keller, S., Koike, M. Maniania, N.K., Monzon, A., Ownley, B.H., Pell, J.K., Rangel, D.E.N., Roy, H.E. 2009. Fungal entomopathogens: new insights on their ecology. Fungal Ecology 2, 149-159.

Yaginuma, K., 2007. Seasonal occurrence of entomopathogenic fungi in apple orchard not sprayed with insecticides. Japanese Journal of Applied Entomology and Zoology 51, 213-220. 